trionic or overplayed. Certainly one could take other approaches. But at no point do I urge readers to "forget the ideas and watch Burke's performance.” My interest lies in the complex interrelation of his explicit aims and his performance.

Anne Mallory University of Georgia

\section{Moving beyond Eurocentric Theory}

\section{TO THE EDITOR:}

As a member of the MLA for more than fifteen years, and having lived and worked in India most of my life, I read Shu-mei Shih's "Global Literature and the Technologies of Recognition" (119 [2004]: 16-30) with interest. I find the essay relevant to my work as a teacher of several Indian languages and literatures. But what I find puzzling is that Shih, in theorizing perspectives of global literature, succumbs to some sweeping generalizations that suit the Western academy, through a process much dependent on Western postmodernist writing-such as Michel Foucault's concept of technology (although Shih, taking a cue from Teresa de Lauretis, wrests it to suit herself) and the postdifference ethics of the French philosopher Alain Badiou. This reliance on Western thinkers gives one the feeling that theorization, at least now, is the prerogative of the West and that the non-West has to follow, comfortably forgetting the Buddhist and other non-Western philosophers who could surely supply much-needed alternative conceptual bases for theory.

This reminds me of the neglect of native and regional languages in favor of English in countries like India-baffling, considering the number of people for whom these regional languages are vehicles of thought and feeling. I note, too, that the production centers of these kinds of postcolonial theory are not Third World universities but universities and publication departments of the West. Shih's mention of Gao Xingjian (who holds a degree in French and lives in Paris while he writes to his diasporic audience) and Mahaswata Devi (who has been introduced to the West by Gayatri Spivak, a postcolonial theorist familiar in the West and the translator of Derrida's of Grammatology) may not be not enough to shift the familiar paradigm of discourse that is produced by the West, for the West. In Shih's group of writers the only exception is Aijaz Ahmad, an Urdu writer with ample knowledge of Indian literature who seems to have moved back to India from the West and writes less now about the problems for which Western writers often quote him.

I am not recommending a binary opposition of West versus East in theory. I am noting the politics of readership of these theories and observing the emergence of an overall picture of how dissent should be manufactured-or should we say "the technology of dissent"? Whether the globalization mechanism is recognition or re-cognition, the products of such theories are the products of a game based in the West, designed according to the market rules of the Western society and its academy.

Moretti's point that the modern novel rose between 1750 and 1950 is attractive, I think, to any student of literature in Indian languages, which count more than eighteen. But in all these languages, without exception, the genre arose roughly between 1850 and 1950, if you include all kinds of experiments in the form. If Shih's theory of technology is relevant, it is only through a comparison of these native novels with their counterparts in England. But this kind of comparative postcolonial study is a rarity, since many scholars who work in Western English departments have neither knowledge of nor interest in what really happened in these native languages during the colonial era, when the genre of the novel put down roots. I believe that even if Moretti's characterization of the Third World novel as Western plot with local characters and local narrative voice is sweeping, his observation can be useful in understanding the complex mechanism of the Indian novel's global identity and difference and in charting all the shades of multifarious meanings that run through the West-East correspondences of this short period.

Sabarimuthu Carlos Warsaw University

Reply:

I read Sabarimuthu Carlos's letter with great interest. It appears to make two main points: The first is that my critique of Western theory ends up reaffirming the importance of Western theory by neglecting alternative theoretical paradigms from the 